\title{
AMERICAN EXPERIMENTATION IN MEETING MEDICAL NEEDS BY VOLUNTARY ACTION*
}

\author{
Martin W. BROWN†
}

\section{I}

For many decades, various groups in this country have been seeking a solution to the several economic problems of medical care. But it is only in the past few years that people have been faced with a situation where the costs of illness can vary excessively. This problem of varying costs of illness arose as a result of the explosive expansion of medical science. Beginning more than $5^{0}$ years ago and continuing to the present time, this proceeded without regard for the economic consequences. The development of medical institutions and equipment, the differentiation of medical knowledge into myriad fields of specialization, has been haphazard. This has resulted in numerous new services, charges for which are now found in the medical bill.

Where in the r880's the doctor received almost roo per cent of the expenditures for medical care, he now receives approximately 40 per cent ${ }^{1}$ and this is divided between the general practitioner and a corps of specialists. But the doctors are not receiving less; the patients are paying more. When today's patient makes his first visit in any illness to the office of the doctor, he can have no idea what the ultimate cost to him will be. He knows that the visit will cost $\$ 2, \$ 3$ or $\$ 5$. But he cannot foretell whether the doctor will call for laboratory tests, $\mathrm{x}$-rays or special diagnostic work. He does not know whether the physician will recommend hospitalization and surgery. For each of these he must pay: The bill for medical care, composed of items for many different kinds of services, may total hundreds of dollars. Experience has indicated that the burden of these varying costs can be met by spreading them over a large group of people, each person paying his proportional share, in other words, by insurance. It is the cost problem that most of our current experimentation is designed to meet.

- This paper is devoted to a consideration of voluntary medical service plans. Its scope does not include consideration of the numerous experiments under governmental auspices or group hospitalization plans. While the latter are significant as illustrating a partial solution to present problems and have a definite place in the scene of American Experimentation, it has been left for following articles on these plans to develop.

+ B.A., 1934, LL.B., I936, Columbia University. General Secretary, Bureau of Cooperative Medicine; Executive Secretary, Association of Medical Cooperatives; Vice-President, Group Health Association of New York; Editor, Cooperative Health; Co-author of The Changing Scene of American Medicine (I939) MEDicine TODAy \& ToMorrow, and articles on group medicine.

${ }^{2}$ Falk, Klem \& Sinal: The Incidence of Illness and the Receipt and Costs of Medical Care Among Representative Family Groups (1933) Publication of the Committee on the Costs of Medical Care, No. 26, 15 I, table 30. 
This situation is far different from that which led to our first efforts to plan the distribution of medical service. Back in the ' 1880 's several industries, particularly mining and lumbering, drew employees away from more settled communities into areas isolated from the conveniences of the larger towns and cities. These industries were, by their very nature, hazardous; income was generally low and irregular. Physicians and other medical personnel or agencies were loath to establish themselves in these isolated mining or lumbering camps as economic, professional and cultural inducements were lacking. Yet to make medical resources available was a matter of vital importance. This was effected by a relatively simple arrangement. A fund was accumulated by deductions from the employees' wages, and the money thus obtained was used to remunerate physicians hired by the companies to settle in these camps and serve the employees. ${ }^{2}$ The problem that was solved by this device was that of making facilities available. It was in no way related to the problem of varying costs.

\section{II}

American experimentation, seeking a solution for the problems created by the development of the science of medicine, has taken innumerable forms. The scope of present experimentation can best be illustrated by examination of the eight most illuminating plans. These are (I) The Ross-Loos Medical Group; (2) The Roanoke Rapids Community Service; (3) Stanocola Employees' Medical and Hospital Association; (4) The Spaulding Bakeries Employees' Mutual Benefit Association; (5) The Mutual Aid Society of the Consolidated Edison Plan; (6) The King County Medical Service Bureau; (7) The Saskatchewan Municipal Doctor System; (8) The plan of the Transport Workers' Union. The comparative study of plans for the extension of medical care, such as those listed above, will be facilitated by reference to the accompanying chart in which the points of difference in the various mechanisms are classified under six principal headings. ${ }^{3}$

Charit for the Comparison of Methods for Extension of Medical Carz*

\begin{tabular}{ccc}
$A$ & $B$ & $C$ \\
Time of & Method of & Method of \\
Payment & Participation & Financing \\
\hline
\end{tabular}

r. Non-payment

2. Post payment installment

3. At receipt of service

4. Periodic prepayment
I. Compulsory

2. Voluntary

(a) Individual

(b) Group

I. Fees

2. Insurance premiums

3. Taxes

4. Philanthropy

5. Employer contributions

6. Contributed services (doctors in hospitals, care of indigent clients)

- Conceived by Dr. Kingsley Roberts, Bureau of Cooperative Medicine.

${ }^{2}$ Wirltams, Medicai Care Through Fised Periodic Payments (1932); Bureau of Cooperative Medicine, Medical Care in Selected Areas of the Appalachian Bituminous Coal Fields (1939).

${ }^{3}$ To illustrate the use of the chart, the components of the Ross-Loos Medical Group Plan are, $\mathrm{A}_{4}$, $\mathrm{B}_{2}(\mathrm{~b}), \mathrm{C}_{2}, \mathrm{DI}_{1}, 2,3,4,8,10, \mathrm{E}_{4}, \mathrm{~F}_{7}$, while for the Municipal Doctor system are $\mathrm{A}-, \mathrm{B}_{1}, \mathrm{C}_{3}, \mathrm{DI}_{1}$, $\operatorname{EI}, \operatorname{Fr}(c)$. 


\begin{tabular}{|c|c|c|}
\hline $\begin{array}{c}D \\
\text { Scope of Service } \\
\text { Provided }\end{array}$ & $\begin{array}{c}\mathbf{E} \\
\text { Method of } \\
\text { Distribution }\end{array}$ & $\begin{array}{c}\mathrm{F} \\
\text { Method of } \\
\text { Administration }\end{array}$ \\
\hline $\begin{array}{l}\text { I. General Practitioner } \\
\text { 2. Specialist (including } \\
\text { surgical) } \\
\text { 3. Diagnostic } \\
\text { 4. Hospital } \\
\text { 5. Special nursing service } \\
\text { (a) hospital } \\
\text { (b) home } \\
\text { (c) school } \\
\text { (d) visiting } \\
\text { 6. Dental } \\
\text { 7. First aid } \\
\text { 8. Health conservation } \\
\text { and education } \\
\text { 9. Other institutional } \\
\text { 10. Drugs \& Supplies } \\
\text { 11. Other }\end{array}$ & $\begin{array}{l}\text { I. Solo General } \\
\text { Practitioner } \\
\text { 2. Solo Specialist } \\
\text { 3. Panel with or without } \\
\text { "unit" system. } \\
\text { 4. Group practice } \\
\text { (a) hospital } \\
\text { (b) private clinic }\end{array}$ & $\begin{array}{l}\text { I. Government } \\
\text { (a) Federal } \\
\text { (b) State } \\
\text { (c) Municipal } \\
\text { (d) County } \\
\text { 2. Medical Society } \\
\text { 3. Profit insurance } \\
\text { 4. Employer } \\
\text { 5. Hospital Staff. } \\
\text { 6. Private doctor group } \\
\text { 7. Entrepreneur } \\
\text { 8. Group Health } \\
\text { Association }\end{array}$ \\
\hline
\end{tabular}

\section{(1) The Ross-Loos Medical Group}

The Ross-Loos Medical Group was originally organized in rg29 in Los Angeles, California, to render medical service to the employees of the Department of Water and Power of the city. The service was expanded when contracts for service were signed with other employed groups and in 1936 the Group leased a four-story building to house the growing clinic.

Financial and professional arrangements between the clinic and groups of subscribers are negotiated by specially organized health committees in each group. All complaints and adjustments are made through these committees. At the present time, there are approximately 21,000 employed subscribers representing more than rro different groups of persons, constituting with their families over 60,000 people.

The Group is owned and operated by a medical co-partnership of ig of the 69 full-time staff physicians. The staff has its offices either in the main clinic or in one of the ten branch clinics located in the suburbs. ${ }^{4}$ These facilities have been specially designed for the particular type of practice engaged in.

For $\$ 2.50$ per month, the Clinic agrees to provide for the subscriber, ${ }^{5}$ medical services of general practitioners, specialists and surgeons in the home, clinic, or hospital. Services also include laboratory work, $x$-ray services, physical therapy treatments, eye refractions, drugs and dressings and hospitalization. Dependents of members may receive all professional services at 50 cents for each office call, \$I for each resident call and other small charges for special procedures, such as $\$ 25$ for a major operation. The average charges for service to dependents is $8 \mathrm{I}$ cents per month

A branch clinic has been recently opened in San Francisco, details of which are not available as yet.

'Individuals may now subscribe for service at a $\$ 3$ per month premium. 
per family. The average of I5.8 office calls (excluding calls for operative procedures) per year per average family of 3.2 persons indicates the volume of service rendered.

\section{(2) The Roanoke Rapids Community Service}

In Roanoke Rapids, North Carolina, there is a community plan supported by the employees of three mills and two other local concerns. Each mill supplies and maintains a small clinic which serves as offices for seven of the ten available physicians. At the local hospital there are two full-time surgeons; and an ear, nose and throat specialist has his own office. The mills also support one full-time nurse.

For the services of the seven clinic physicians, the ear, nose and throat specialist and the visiting nurse, the employees of these concerns pay 25 cents per week. For the services of the two surgeons and for hospitalization, they pay an additional 25 cents per week. These premiums assure coverage for dependents as well as the employee. About 5,000 persons are covered by these arrangements. The premiums are collected by payroll deduction and are turned over by the concerns to the auditor for the companies. The latter keeps the books for the plan and distributes the funds collected. Before I93I the concerns contributed half the fund. Since then they have limited their support. In r93I the employees voted to increase their contributions to those noted above so that the service could be continued. A study in ${ }^{6} 930$ of the services rendered revealed that among the persons covered, $x .8$ visits per person were made per year, while among the remaining uninsured population only 4 visits were made.

\section{(3) Stanocola Employees' Medical and Hospital Association}

This association in Baton Rouge, Louisiana, is an organization of the white employees of the Standard Oil Company of Louisiana. It was first organized 15 years ago to provide medical service to the members and their families. These services now include medical care rendered by Ir full-time physicians (including two surgeons, an eye, ear', nose and throat specialist, a pediatrician and an anaesthetist), laboratory tests, $\mathrm{x}$-ray and other diagnostic services. Hospitalization and private duty nursing benefits, when recommended by a member of the medical staff, are included up to a maximum cost of $\$ 250$ for a single illness.

The Association owns a clinic building which it purchased in 1938, has its own board of directors and officers, and is nominally independent of the Standard Oil Company. Membership in the Association is voluntary, yet about 90 percent of the eligible group has joined. Dues are $\$ 3$ per month. In January 1928, the Board was given permission to levy three special assessments of $\$ 3$ each in any calendar year. This-authority is exercised twice a year.

In 1930 the Association was incorporated, and each member is required to purchase a share of stock. Funds so received constitute the capital and reserve funds of the Association.

\footnotetext{
- Falk, Griswold, Spicer, A Community Medical Service Organized under Industrial Auspices in Roanoke Rapids, Noth Carolina. (1932) Publication of the Committee on the Costs of Mídical CARE, No. 20.
} 


\section{(4) The Employees' Mutual Benefit Association of the Spaulding Bakeries}

This association in Binghamton, New York, was organized in 1930 for the purpose of providing cash benefits and medical care and hospitalization during sickness. The Association is divided into plant divisions, and a Board of Trustees appointed by the company is in charge of the administration of each division. The funds of each division are administered separately. The dues paid by employees vary according to their weekly wage from a minimum of 20 cents per week to a maximum of 45 cents. The company contributes about $\$ 2$ per month for each employee, as well as room and clerical assistance.

Upon application to the Trustees, a member may receive benefits as follows: $\$ 3$ for house calls and $\$ 2$ for office visits up to a maximum of $\$ 50$ in any one year; designated cash benefits for surgical procedures such as a $\$ 100$ limit for major operations. A hospital benefit of $\$ 3$ per day not to exceed $\$ 90$ is provided. Members have free choice of any physician or hospital in the locality. The five year average cost has been $\$ 25.47$ per employee per year. Dependents are included for \$I per family per month with expenditure limited to $\$ 50$ a family in any one year.

A supervisory committee of three physicians, one appointed by the medical society, passes on medical bills whenever there is a question of exorbitant charges, padding or unnecessary services.

\section{(5) The Mutual Aid Society of the Consolidated Edison Company}

The present plan of the Consolidated Edison Company in New York City was developed in r935. It is intended to cover all the 40 to 50,000 employees of the company and its affiliates. The employees earning less than $\$ 46$ per week are organized into a voluntary Mutual Aid Society. The company deducts $\%$ of I percent from weekly salaries (average $\$ 32.40$ ) and itself contributes additional sums so that an annual fund of $\$ 1,100,000$ is established to pay for care required by members during the year. The financial affairs of the Society are administered by the Company.

The Society contracts with a limited number of physicians to furnish home and office care. It has also.arranged with certain hospitals to provide unlimited hospital services in wards at $\$ 4$ per day. The physicians and surgeons who perform the services are paid on a fee for service basis according to a minimum fee schedule. The Society has ruled that no physician shall receive more than $\$ 1,200$ per year from payments for services rendered to members.

\section{(6) The King County Medical Service Bureau and Corporation}

The King County Medical Service Bureau in Seattle, Washington, is one of fourteen developed to meet a situation created by a provision of the State Workmen's Compensation Law permitting private corporations to contract with employers to render medical service. The Bureau is a voluntary association of physicians who have agreed to furnish services to the King County Medical Service Corporation. This corporation is a non-profit organization that contracts with employers to provide medical and surgical care, hospitalization, nursing and ambulance services to the 
employees. The Corporation in turn contracts with the physicians of the Bureau, with hospitals and other agencies for the provision of the services. About 32,000 employees covered by contract receive services from the $45^{\circ}$ physician members of the Bureau.

The Corporation sells two contracts, one for compensable injuries and the other for sickness and non-compensable injuries. In the case of the latter contract, the employee pays the premium through payroll deduction. The premiums range from $\$ 1.25$ to $\$$ I.75 per month.

The physicians of the Bureau and the Corporation agree upon a fee schedule. Payments are made to the doctors under the unit system. ${ }^{7}$ The organization is administered by a medical director and a sales director who runs the office and sells contracts. A medical audit committee examines the physicians' monthly statements of services rendered.

\section{(7) The Saskatchewan Municipal Doctor System}

In the Province of Saskatchewan, Canada, 84 rural municipalities, corresponding to a county in the United States, furnish medical services to the inhabitants at municipal expense. In addition, 54 villages and four towns employ municipal physicians. Altogether 179,254 persons or I9 percent of the provincial population live in communities where medical services are paid for through general taxation.

The salaries paid to the municipal physicians range from $\$ 2400$ to $\$ 6000$ per annum, the average being $\$ 4,000$. Where the salary is comparatively low, the doctor is usually permitted to charge for an initial home call during an illness or for special services such as a confinement. However, under the terms of the average contract between municipality and physician, the doctor is to provide general medical services and obstetrical care and to perform minor surgery. He also acts as public health officer. Out of the salary paid the physician, he must maintain an office and pay his own expenses.

The system is primarily a method of obtaining or retaining resident physicians in the municipalities. It has also come to be regarded as a simple method of arriving at a more equitable distribution of the costs of medical care.

In II municipalities, physicians are subsidized by annual grants up to $\$ 1500$ per year. In 59 municipalities and 7 towns, hospital care and treatment is provided. The system is being extended to the Provinces of Alberta and Manitoba.

\section{(8) The Plan of the Transport Workers' Union}

The New York Local Transport Workers' Union have recently instituted a medical program for its members. The service will be financed primarily from the union's treasury and the receipts from two benefits each year. The estimated cost of providing general practitioners' and specialists' care to the 55,000 members is $\$ 170,000$. The services, free to members, are rendered by a panel of 52 full-time physicians and

\footnotetext{
' Under this method, each service is allotted a specified number of units. The total number of units of service during a month is divided into the amount of money available to pay medical bills, and each participating physician is paid the resulting unit value for the units of service he has rendered.
} 
specialists. Each general practitioner will have a list of about 1000 members. The doctors will be paid on a salary basis but will maintain their own offices rather than practice as a group. The services will be administered by a committee of union officials.

\section{III}

The eight plans outlined in the preceding section reveal the differences on fundamentals that prevail on the scene of American experimentation. These are: ( $I$ ) Should membership in a plan be limited to a specific group in the population as employees of a common employer, members of a labor union, a club or fraternal order, or should it be open so that any resident of the community may associate himself with it and avail himself of its advantages? (2) Should benefits be cash reimbursement to defray expenses for medical care or the medical care and attention itself? (3) Should the services be rendered by a group of full-time physicians utilizing common offices and equipment, by a restricted panel of physicians each maintaining his own office, or by any physician in the community who desires to participate? (4) Should the physicians be remunerated on the basis of salary or fee for service?

First, should membership or participation in the plan be limited to a specific group in the population or should it be open so that any resident of the community may associate himself with it and avail himself of its advantages? Generally speaking, company or industrial plans have been set up for the employees of the concern and their families. The plans of the Roanoke Rapids Concerns, Standard Oil of Louisiana, Spaulding Bakeries, Consolidated Edison and the Transport Workers' Union proceed on this basis. The Ross-Loos Medical Group entered into subscription contracts only with employed groups until a year ago when individual enrollment was added. This is still the situation in the case of the King County Medical Service Bureau.

The establishment of associations especially organized for the purpose of meeting medical care problems and operated independently of any particular industrial concern is meeting with increasing favor on the part of employers. The development of industrial plans has imposed burdensome tasks upon them. They are generally responsible for the administration, and in most cases contribute sums of money to the plans' funds. 'That the arrangements may be made in the name of an Employees' Mutual Benefit Association ${ }^{8}$ does not alter the situation. Further, it is becoming more and more clear that the administration of these programs is a specialized field requiring personnel trained for that purpose. Another factor stimulating the change of attitude of employers is the growth of labor unions which look upon employee associations with disfavor. These, they feel, smack of company unions and paternalism.

The second question is: Should benefits be cash reimbursement to defray expenses

\footnotetext{
${ }^{a}$ In most cases, the arrangements for medical care are but incidental to other activities of these associations.
} 
for medical care, ${ }^{9}$ or the medical care and attention itself? Of the eight plans noted in Section II, only that of the Spaulding Bakeries pays cash benefits to defray medical expenses.

The problem in the case of cash benefits to defray medical expenses is that adequate data which can be used to estimate claims for such benefits are not available. Yet premiums must be fixed and out of the fund so accumulated must be paid claims according to a fixed fee schedule. As a result, plans of this type have had a precarious existence. They are most successful in industrial concerns where the employer can contribute to and replenish the funds as may be necessary. Several proposals have recently been made to establish such plans independent of any employer and with an open membership. These proposals have generally been made subsequent to the endorsement in 1938 of this form of health insurance by the A.M.A.

Evidence would tend to indicate that the present trend however.is towards service benefits. Many Employee Mutual Benefit Associations are adding benefits in service to cash benefits during periods of disability. ${ }^{10}$ Many state and county medical societies have advanced proposals for benefits in service despite the position of the A.M.A.

The third question is: Should the services be rendered by a group of full-time physicians utilizing common offices and equipment, by a restricted panel of physicians each maintaining his own office, or by any physician of the community who desires to participate?

The A.M.A. takes the position that any arrangement for the distribution of medical service must be so devised that any physician in the community may, if he so desires, associate himself with the plan. The A.M.A. further favors fee-for-service remuneration of physicians. Advocates of group health plans on the other hand favor the distribution of services through groups of physicians practicing as a unit along the lines indicated by the Mayo Clinic.

A third type of arrangement is sometimes used and this is illustrated by the plan of the Consolidated Edison Company where participation by physicians is restricted and "free choice" does not exist. Each physician associated with such a plan maintains and practices in his own office independently of the other physicians on the panel. The arrangements of the Transport Workers' Union are also of this type. Such panel arrangements are generally to be found in metropolitan areas where a wide spread of population makes service from a central point or from a single group practice clinic a difficult procedure. At the present time, many of the leaders of the medical profession favor group medical practice as the only medical procedure where the physician and the patient can take advantage of all that modern medical science has made available. ${ }^{11}$

\footnotetext{
- While a great many industrial plans pay fixed sums per week during periods of disability, the objective of such arrangements is to compensate for loss of wages during the period of disability, and, therefore, bears no relation to the specific problems of varying costs for medical service or the availability of facilities.

${ }^{10}$ Nat. Ind. Conf. Bd., Health Insurance Plans: Mutual Benefit Associations, Studies in Personal Policy No. 9A (1938).

${ }^{11}$ Peters, Free Experimentation in Meeting Medical Needs, A Professional View, Address Delivered at
} 
Closely related to the issue of free choice or group practice is that of how shall the doctor be paid? There are two fundamental procedures that are utilized. The doctor may be paid for each unit of service rendered, being assured either payment according to a fee schedule or out of a fund in proportion to the value of services rendered (King County Medical Bureau). The second is to pay the doctor a fixed sum per year, month or week, regardless of the volume of service. This might be paid on a straight salary basis for full-time or part-time work or on a capitation basis for part-time services, i.e., a fixed sum per person per year regardless of the volume of services rendered to any particular person. In the case of a plan paying cash benefits in reimbursement of incurred medical expenses, the method of payment is necessarily fee-for-service. But in the case of a plan where the benefits are the medical services, either of the procedures is possible. The "unit" system ${ }^{12}$ was developed to overcome the lack of actuarial data which may result in a hazardous financial career for the plan. This technique has the advantage of fixing an upper limit of expenditures so far as the plan is concerned. This device is utilized in plans with free choice of physician and in many panel plans. Group practice plans almost universally pay physicians on a salary basis. The capitation arrangement is particularly adapted to panel plans.

The value of the capitation arrangement, which has not found particular favor in this country although it is common practice in European compulsory health insurance schemes, is that it has the great advantage of eliminating the necessity for a check and audit of physicians' services. Such check and audit are essential in the administration of free choice or panel plans paying on a fee-for-service basis. Experience has indicated that unless the statements of physicians as to care rendered are investigated and examined to determine the extent of their responsibility for unnecessary service (which the patient also must share) funds of the plans will be depleted by payment for such services.

In the case of unit system payments, although the abuse of unnecessary calls and treatments would not increase expenditures, if the check and audit were not made, payments for each unit of service would gradually become lower until the welltrained and well-equipped physician could no longer afford to render services under the plan and would have to separate himself from it. Should this happen, poorer physicians would remain and the quality of service would be inevitably lowered.

At the First Annual Convention of Group Health Plans held in New York City last July, the various groups represented undertook the establishment of a national Group Health Federation. The inauguration of an active program by this federation may materially affect the course of future developments in the field of experimentation in meeting the medical needs of people with low incomes.

First Annual Convention of Group Health Plans; Cabot, Address delivered at N. Y. Herald Tribune Forum, N. Y. Herald Tribune, Oct 30, 1938; Winslow, Medical Care for the Nation (1939) 28 YALE Review 501; Sigerist, Socialized Medicine (1938) 27 YALE REview 463; Roberts, Medical Cooperatives, Health and Hygiene, October, I937.

${ }^{13}$ Defined in note 7 , supra. 